\title{
GENETIC DIVERSITY OF OLIVE RIDLEY Lepidochelys olivacea ASSOCIATED WITH CURRENT PATTERN IN CENDRAWASIH BAY, PAPUA
}

\section{KERAGAMAN GENETIK PENYU LEKANG Lepidochelys olivacea DENGAN POLA ARUS DI TELUK CENDRAWASIH, PAPUA}

\author{
Samsul Bahri, Agus S. Atmadipoera, dan Hawis H. Madduppa* \\ Departemen Ilmu dan Teknologi Kelautan, FPIK-IPB \\ *E-mail: hawis@apps.ipb.ac.id
}

\begin{abstract}
Cendrawasih Bay is habitat for olive ridley Lepidochelys olivacea which is directly adjacent to the Pacific Ocean. The presence and the diversity of L. olivacea in Cendrawasih Bay has been threatened. Genetics can be the key to conservation because they play an important role in maintaining population and recovering from damage. This study aims to determine the genetic diversity of $L$. olivacea and its association to the current pattern in the waters of Cendrawasih Bay. Samples of L. olivacea $(n=20)$ were collected in Kwatisore $(n=8)$ and Yapen Island $(n=12)$ in Cendrawasih Bay waters from August 2015 to December 2016. The molecular analysis was based on 791-bp fragment of D-Loop on the noncoding region gen. The current pattern analysis was performed through INDESO data and visualized by using Ferret software. Phylogenetic analysis showed that 2 groups of L. olivacea from a total of 2 haplotypes, whose population from Kwatisore was dispersed in two haplotypes, while the population from Yapen Island was only dispersed in one haplotype. Populations from Kwatisore showed higher variations than populations from Yapen Island. The current pattern analysis suggests that the two study sites, Kwatisore and Yapen islands are different. Both populations are only connected by the Northwest monsoon currents period that indicates a little geneflow between this populations. Thus causing differences variation between Kwatisore and Yapen Island populations genetically.
\end{abstract}

Keywords: genetic diversity, current pattern, coral triangle, olive ridley

\section{ABSTRAK}

Teluk Cenderawasih merupakan habitat bagi penyu lekang (Lepidochelys olivacea) yang berbatasan langsung dengan Samudera Pasifik. keberadaan dan keragaman L. olivacea di Teluk Cenderawasih telah terancam. Genetik dapat menjadi kunci konservasi karena memainkan peran penting dalam mempertahankan dan memperbaiki populasi dari kerusakan. Penelitian ini bertujuan untuk mengetahui keragaman genetik L. olivacea dan pengaruh arus terhadap keragaman genetik di perairan Teluk Cendrawasih. Sampel L. olivacea $(n=20)$ dikoleksi dari Kwatisore $(n=8)$ dan Pulau Yapen (n=12) di perairan Teluk Cendrawasih pada bulan agustus 2015 hingga februari 2016. Analisis molekular dilakukan dari total panjang fragmen 791-bp melalui marka gen D-loop noncoding region. Analisis pola arus dilakukan melalui data keluaran INDESO yang divisualisasikan menggunakan perangkat lunak Ferret. Hasil filogenetik membentuk 2 kelompok L. olivacea dari total 2 haplotipe yang ditemukan dimana populasi yang berasal dari Kwatisore tersebar pada kedua haplotipe, sementara populasi yang berasal dari Pulau Yapen hanya ditemukan pada satu haplotipe saja. Populasi Kwatisore menunjukkan variasi yang lebih tinggi dibandingkan Pulau Yapen. Analisis pola arus menunjukkan bahwa kedua lokasi studi Kwatisore dan Yapen memiliki karakteristik yang berbeda. Kedua populasi hanya dihubungkan oleh periode arus monsun barat laut sehingga terjadi aliran genetik yang kecil antara kedua populasi ini yang menyebabkan perbedaan variasi antara populasi pulau Kwatisore dan Yapen secara genetik.

Kata kunci: keragaman genetik, pola arus, segitiga terumbu karang, penyu lekang 


\section{INTRODUCTION}

Turtles tend to spend their entire lives at sea and migrate far across the Indian Ocean, the Pacific Ocean and Southeast Asia (Whiting et al., 2007). Information related to turtle population in the Indo Pacific region is still limited (Chaloupka et al., 2004). The population of marine turtles in this region has significantly decreased due to over exploitation (Limpus, 1997). Six of the 7 species of turtles that exist in the world, namely olive ridley turtle (Lepidochelys olivacea), green turtle (Chelonia mydas), hawksbill turtle (Eretmochelys imbricata), flatback turtle (Natator depressus), leatherback turtle (Dermochelys coriacea) and loggerhead turtle (Caretta caretta) live in Indonesian waters. Turtles are included in the red list of IUCN and Appendix I CITES indicating that wild turtles has been threatened with extinction (Baillie et al., 2004). The occurrence of turtles has long been primarily threatened by human activities that endanger the population directly and indirectly.

The dramatic decline in the turtle population is mainly due to the consumption of turtle eggs, turtle meat trade and habitat destruction caused by changes in natural conditions (Meylan and Donnelly, 1999). The population and habitat of olive ridley nests (L. olivacea) are spread globally in tropical waters (Bowen et al., 1998). According to Polovina et al. (2004), L. olivacea has the largest population distribution of nests in the Indian Ocean and the Pacific Ocean. This species belongs to the Cheloniidae family which morphologically has a smaller body size compared to the other 6 species of turtles with a weight ranging from 50 to $75 \mathrm{~kg}$ and a body length of 150 centimeters. The carapace has grey color on the upper part and gray-cream colored on the bottom part of its body (Polovina et al., 2004)) and has more than five vertebral scales (Polovina et al., 2004; Dermawan et al., 2009). Differennt from the other species, they used to spawn at the same time in a large quantity during the day known as arribada in Mexico and India (RodríguezZárate et al., 2013). Exploitation of these 6 species has been prohibited through the Government Regulation of Republic of Indonesia Number 7/ 1999 on the turtle protection, and this has also been confirmed by the Ministerial letter number 526/MENKP/VIII/ 2015 on turtle utilization banning.

The molecular technique has been largely utilized as genetic markers and genetic identification as well as for other ecological studies that still have found no answers in detail through the ecological approach (Madduppa et al., 2016; Prehadi et al., 2015). The genetic approach has been largely done in the process of identifying species, population structure and genetic diversity of a population or individual (Madduppa et al., 2016). Research on the diversity and genetic flow of L. olivacea in Indonesian waters is still very little known. Those few studies which have been conducted in Indonesia such as an green turtle (Cahyani et al., 2007) and Leatherback turtle (Maslim et al., 2016).

Phylogenetic trees can be used as kinship references based on geographic location that can indicate individual and species kinship through phylogenetic tree reconstruction (Zuazo et al., 2010). The haplotypes and nucleotides diversity can serve as a parameter to analyze the genetic richness of species in a population (Kochzius et al., 2008). Data on connectivity are also urgently required to design effective conservation strategies for L. olivacea. One of the most widely used markers in genetic research is Mitochondrial DNA (mtDNA). The mtDNA has been widely used as a marker in genetic observations such as identification, population structure and genetic diversity (Saleky et al., 2016). This is a maternally-derived genetic material that can be used as a genetic marker and in the genetic studies of sea turtle populations (Cahyani et al., 2007). 
Turtles tend to spend their whole lives and move in the open ocean, and this movement is strongly influenced by the oceanographic factors. Several observations have been made to prove the possible influences of turtle movement on marine oceanography (Luschi et al., 2003). Despite the large differences in living and eating habits, these seven known species of turtle still have nearly the same life cycle covering a long period at all stages of development (Musick and Limpus, 1997). Current is one of the major factors affecting the movement of sea turtles, resulting in great force in their migrating activities (Luschi et al., 2003).

The current pattern in Indonesia is influenced by two mainstream systems, namely, the Indonesia Monsoon Current (Armondo) which occurs due to the influence of monsoon wind that changes its direction twice a year and the Indonesian Throughflow (Arlindo) as a persistent current system from the Pacific Ocean to the Indies through the Indonesian Sea (Atmadipoera et al., 2016). The Indonesian throughflow comes from two different water mass components, from the northern Pacific and from the southern Pacific (Ilahude and Gordon, 1996).

The northern Pacific water mass is pulled by the Mindanao current and follows the western route through the eastern Sulawesi Sea to Makassar Strait and then to Flores Sea, and approximately $20 \%$ of the water mass of the Indonesian Throughflow flows into the Indian Ocean through Lombok Strait (Murray and Arief, 1988) while the South Pacific water mass has a very small role in the phenomenon of the throughflow (Gordon and Fine, 1996).

The effects of the oceanographic environmental factors on turtle movement are little known and only a few have been made through the tagging approach on turtles (Horrocks et al., 2001). Identifying the effects of oceanographic factor like currents is crucial in studying the patterns of turtle distribution and migration. This study was expected to be a preliminary research to the genetic diversity of L. olivacea and their association with current pattern in Cendrawasih Bay.

Cendrawasih Bay which is directly adjacent to the Pacific Ocean (Mustikasari et al., 2015). Genetics can be the key to conservation because they play an important role in maintaining population and recovering from damage. Therefore, information on genetic diversity is necessary for of the implementation of sustainable management in marine protected areas (Kusuma et al., 2016). As the ater flow patterns affect the distribution of marine life, especially the larvae and juveniles, thus reducing the risk of predation for them compared to coastal areas and shallow waters (Collard, 1990). The purpose of this study was to determine genetic diversity of olive ridleys ( $L$. olivacea), associated with the current pattern in Cendrawasih Bay.

\section{METHODS}

\subsection{Study Period and Sites}

The study was conducted from August 2015 to December 2016 innitiated by collecting samples at 2 different sites, namely, Kwatisore and Yapen Island within Cenderawasih Bay (Figure 1) during the nesting season from mid to late year. .

\subsection{Sample Preparation}

The samples collected were alive and dead hatchling (baby turtles). The sample was taken from one part of the front legs of L. olivacea tissue. The procedure of tissue preparation as recommended by Eckert et al. (1999), put in a $1.6 \mathrm{ml}$ tube containing $96 \%$ ethanol solution, and repeatedly replaced until the color change, and then transferred to the laboratory for further laboratory analysis.

\subsection{Analysis of Genetic Diversity}

DNA isolation from tissue samples was conducted at the Marine Biodiversity and Biosystematics Laboratory, Department 


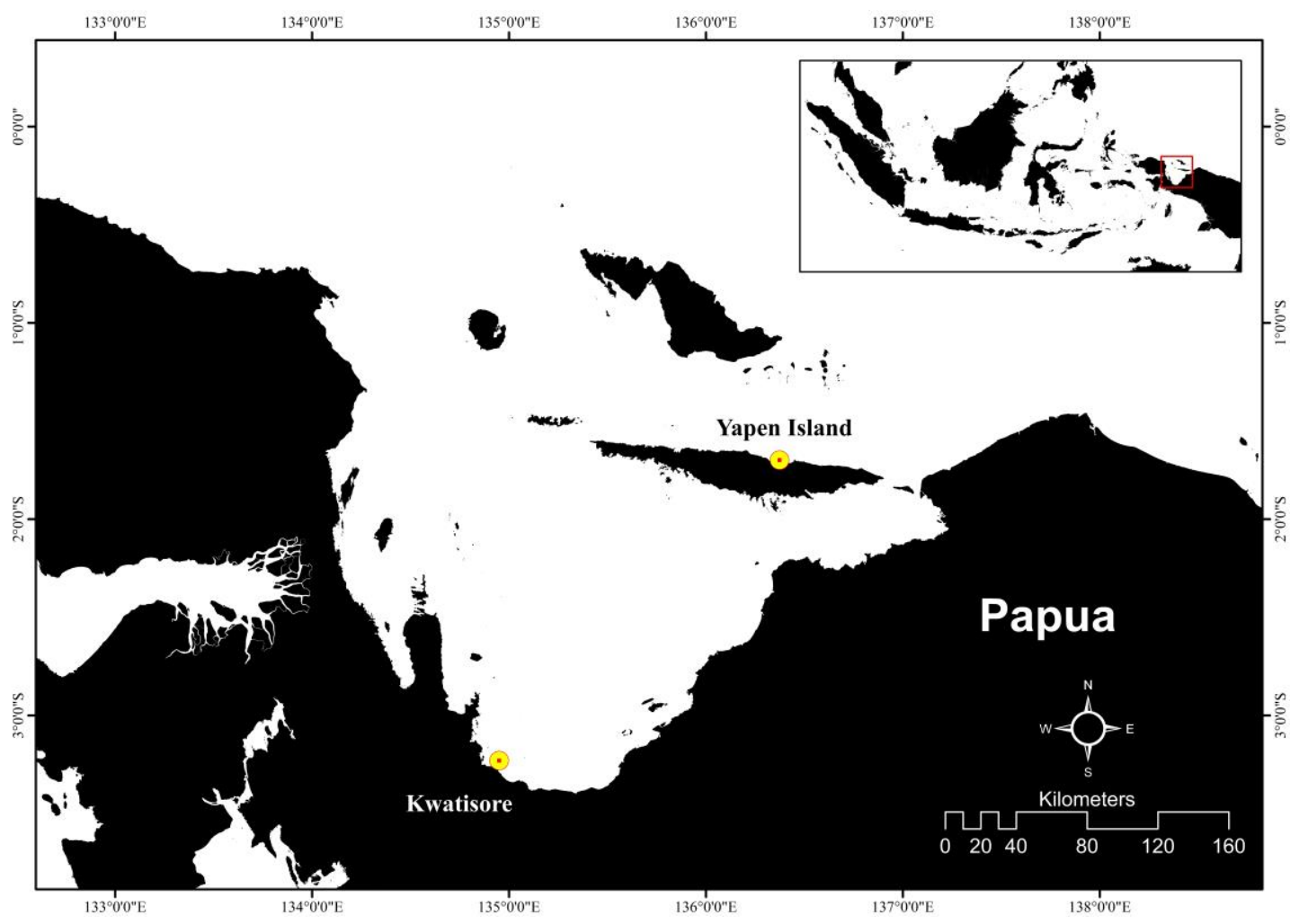

Figure 1. Study sites at Kwatisore and Yapen Island within Cenderawasih Bay, Papua, Indonesia.

of Marine Science and Technology, Faculty of Fisheries and Marine Sciences, Bogor Agricultural University. Genetic analysis was conducted through mitochondrial DNA (mtDNA) in the D-loop gene (non-coding region). mtDNA extraction was performed by using $10 \%$ chelex solution to separate the mtDNA component from other compounds (Walsh et al., 1991). The chelex solution composition consists of a molecular water solution and $100 \%$ resin which has been mixed with a ratio of 10 grams of resin powder and $100 \mathrm{ml}$ of molecular water. The amplification of the DNA product was performed using the PCR technique (Polymerase Chain Reaction) with the LTEi9 front primer (GGGAATAATCAAAAGAG AAGG) and the H950 rear primer (GTCTC GGATTTAGGGGTTTG) as recommended by Alberto Abreu-Grobois et al., (2006). PCR was performed in the conditions of $2 \mu 1$ template DNA, $10 \mu \mathrm{lddH} 2 \mathrm{O}, 1.25 \mu \mathrm{l}$ front and rear primers $(10 \mathrm{mM})$, and ready mix
12.5 $\mu$ KAPPA. The PCR technique process was carried out using PCR machine (thermo cycler) with the 38 total cycles. Each cycle consists of denaturation at $94^{\circ} \mathrm{C}$ for 30 seconds, annealing at $50^{\circ} \mathrm{C}$ for 30 seconds, and extension at $72^{\circ} \mathrm{C}$ for 45 seconds, and this was then continued with the final elongated activity at $72^{\circ} \mathrm{C}$ for 5 seconds. The PCR product was further sequenced using mega 6 software for further analysis.

Phylogenetic tree reconstruction was analyzed using Neighbor Joining method with 1000x bootstrap replications through MEGA application (Tamura et al., 2011). This analysis used DNA Sequence Polymorphism software (Rozas et al., 2003) as a standard measure in calculating the genetic diversity that includes the diversities of haplotypes $(H d)$ and nucleotide $(\pi)$.

\subsubsection{Current Pattern Analysis}

The data used were the output of the INDESO (Infrastructure Development of 
Space Oceanography) current pattern model from the model simulation conducted by CLS France, as part of the INDESO program of the Ministry of Marine Affairs and Fisheries (http://indeso.web.id/) (Atmadipoera et al., 2016). The INDESO model is a current pattern model using the NEMO model system (Madec, 2015). The INDESO model configuration is described by Tranchant et al. (2015). In summary, this model configuration is the horizontal resolution of this model $1 / 12^{\circ}$ with 50 depth levels with closer vertical resolution near the surface; the model was driven by the atmospheric forcing of ECMWF and barotrophic tide forcing of TPOX07; and the lateral limit applied the data of the currents and sea water properties (temperature and salinity) from the output of the global Pattern model of MERCATOR Tranchant et al. (2015). The data used in this thesis included daily average time series data for zonal current components, meridional currents, temperature, and salinity near surface (the surface was up to $6 \mathrm{~m}$ ) in 2015 . The sea current pattern was analyzed using Ferret software operated through the LINUX operating system in its processing (Horhoruw, 2016). This circulation is expected to provide additional information on the possible spread of juveniles or migrating adult turtles in the three areas, and may help explain their biogeographic kinship relationship.

Ferret is a software tool that allows it to visualize and simulate a current vector that can be combined with salinity and temperature data that can be conducted offline. Data visualization was carried out through the results of the analyses on the current vector images current movement simulation. The image output data were analyzed from the vector data (zonal and meridional) that had been combined with the temperature and salinity data averaged each month for one year while simulation data were analyzed with the animated images from the vector data (zonal and meridional) which had been combined with the simulated temperature and salinity data for one year (365 days).

\section{RESULTS AND DISCUSSIONS}

\subsection{Results}

\subsubsection{Genetic Diversity}

The phylogenetic reconstruction of the 2 populations of $L$. olivacea was conducted using the Neighbor Joining method (Figure 2). The out-group sequential data used in this study were kempii turtle type ( $L$. kempii) which is the closest relative of the olive ridley species (L. olivacea) (Bowen et al., 1998). Other sequential data originating from Australia were also downloaded on GenBank to be used as comparative data from data obtained from the L. olivacea population living in Kwatisore and Yapen Island.

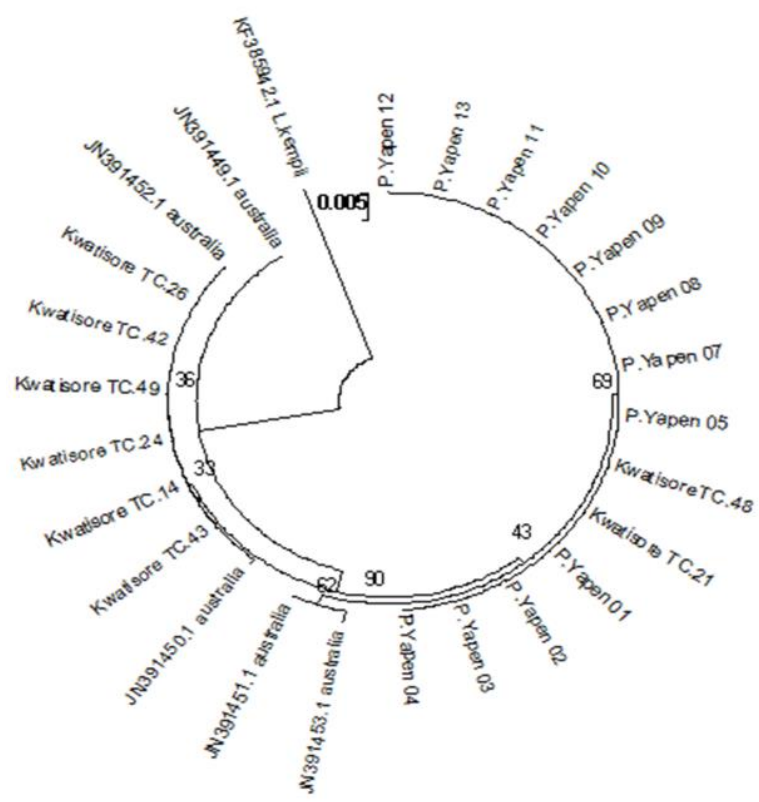

Figure 2. Phylogenetic tree of L. olivacea from Kwatisore and Yapen island populations constructed using Neighbor Joining $(\mathrm{NJ})$ by Kimura 2-parameter model with 1000 bootstrap.

The results of phylogenetic reconstruction illustrate two separate groups of $L$ olivacea between Kwatisore and Yapen 
Table 1. Genetic diversity of L. olivacea from Kwatisore and Yapen Island populations based on number of samples $(n)$, nucleotide composition, number of haplotype $\left(N_{\mathrm{hp}}\right)$, haplotype diversity $(H d)$ and nucleotide diversity $(\pi)$.

\begin{tabular}{llccccccc}
\hline \multirow{2}{*}{ Populations } & \multirow{4}{c}{$n$} & \multicolumn{9}{c}{ Nucleotide composititions } & \multicolumn{5}{c}{ Genetic diversity } \\
\cline { 2 - 10 } & & $\mathrm{T}(\mathrm{U})$ & $\mathrm{C}$ & $\mathrm{A}$ & $\mathrm{G}$ & $N_{\mathrm{hp}}$ & $H d$ & $\pi$ \\
\hline Kwatisore & 8 & 35.49 & 17.43 & 33.08 & 14.00 & 2 & 0.42857 & 0.001253 \\
Pulau Yapen & 12 & 35.38 & 17.54 & 33.19 & 13.89 & 1 & 0 & 0 \\
\hline
\end{tabular}

populations. However, two individuals from Kwatisore population were found in the branching group of Yapen Island population. The population of L. olivacea originating from Australia also downloaded and included in the phylogenetic tree as comparison data where the population of this region tends to be close related to Kwatisore and Yapen Islands populations genetically.

The results of the genetic diversity analyses of $L$. olivacea in Kwatisore and Yapen Island populations showed a contrasting variation between these two populations (Table 1). From the results of the analyses, 2 haplotypes of the 2 populations of Kwatisore and Yapen were found. The 2 haplotypes of L. olivacea of the total of 8 individuals were found in Kwatisore popu-lation whereas in Yapen Island population, there was only one haplotype of L. olivacea in a total of 12 individuals was found. Haplotype $(H d)$ and nucleotide $(\pi)$ diversities in Kwatisore population were 0.42857 and 0.001253 respectively whereas the wo para-meters for Yapen Island population were both zero. The percentages of nucleotide composition obtained in both populations tend to be equal between $\mathrm{A}+\mathrm{C}$ and $\mathrm{G}+\mathrm{T}$ compositions where the ratio of nucleotide $\mathrm{A}+\mathrm{C}=\mathrm{G}+\mathrm{T}$ were $50.51=49.49$ in Kwatisore population and $50.73=49.27$ in Yapen Island population (Table 1).

\subsubsection{Current Pattern}

The eastern archipelago is unique because there are a number of physical and chemical factors influenced by the Pacific Ocean due to its geographical location directly adjacent to this ocean. The region between Mindanao and Halmahera becomes the entrance of the Indonesian Throughflow with Makassar Strait as the main portal that brings water mass from the Pacific Ocean to the Indian Ocean. This Throughflow occurs due to the blowing of the southern Pacific wind in the southern part of the Pacific region of Indonesia, resulting in gradient differences between the waters of the Pacific Ocean and the Indian Ocean. During the Northwest monsoon period (e.g. in January), the current vectors show the movement of water masses from Flores Sea and Timor Sea to Banda Sea and Arafura Sea while in the northern waters of Papua Coast, the current vectors show the movement of water masses to Papua New Guinea peninsula through Cendrawasih Bay (Figure 3 and 4). During the Southeast monson (e.g. August), the current vectors show the movement of water masses from Arafura Sea to Timor Sea, the Indian Ocean, Banda Sea, Flores Sea to Java Sea while in the northern part of Papua, more dominant movement of current vectors occurs from the Papua New Guinea peninsula to the Halmahera waters through Cendrawasih Bay (Figure 3 and 4).

The distribution of surface temperature in the eastern region tends to vary during the Northwest and Southeast monsoons. The surface temperatures in Arafura Sea, Banda Sea and Timor Sea tend to be higher during the Northwest seasons where the temperature range reaches between $29^{\circ} \mathrm{C}$ and $32^{\circ} \mathrm{C}$, while in the southeast seasons, surface temperatures in the Arafura Sea, Banda Sea and Timor Sea tend to be lower with a temperature range between $25^{\circ} \mathrm{C}$ and $28^{\circ} \mathrm{C}$. Temperatures in the northern waters of Papua 
tend to be more uniform throughout the year where the temperature range reaches between $29^{\circ} \mathrm{C}$ and $32^{\circ} \mathrm{C}$. The distribution of salinity in the eastern region tends to be not significantly different throughout the year. However, in the northwest season, the salinity of the waters in Arafura Sea, Banda Sea and Timor Sea and northern Papua tends to be lower with the salinity ranges from 32 to $33 \mathrm{psu}$ while in the southeast season salinity is higher with the range from 33 to 35 psu.

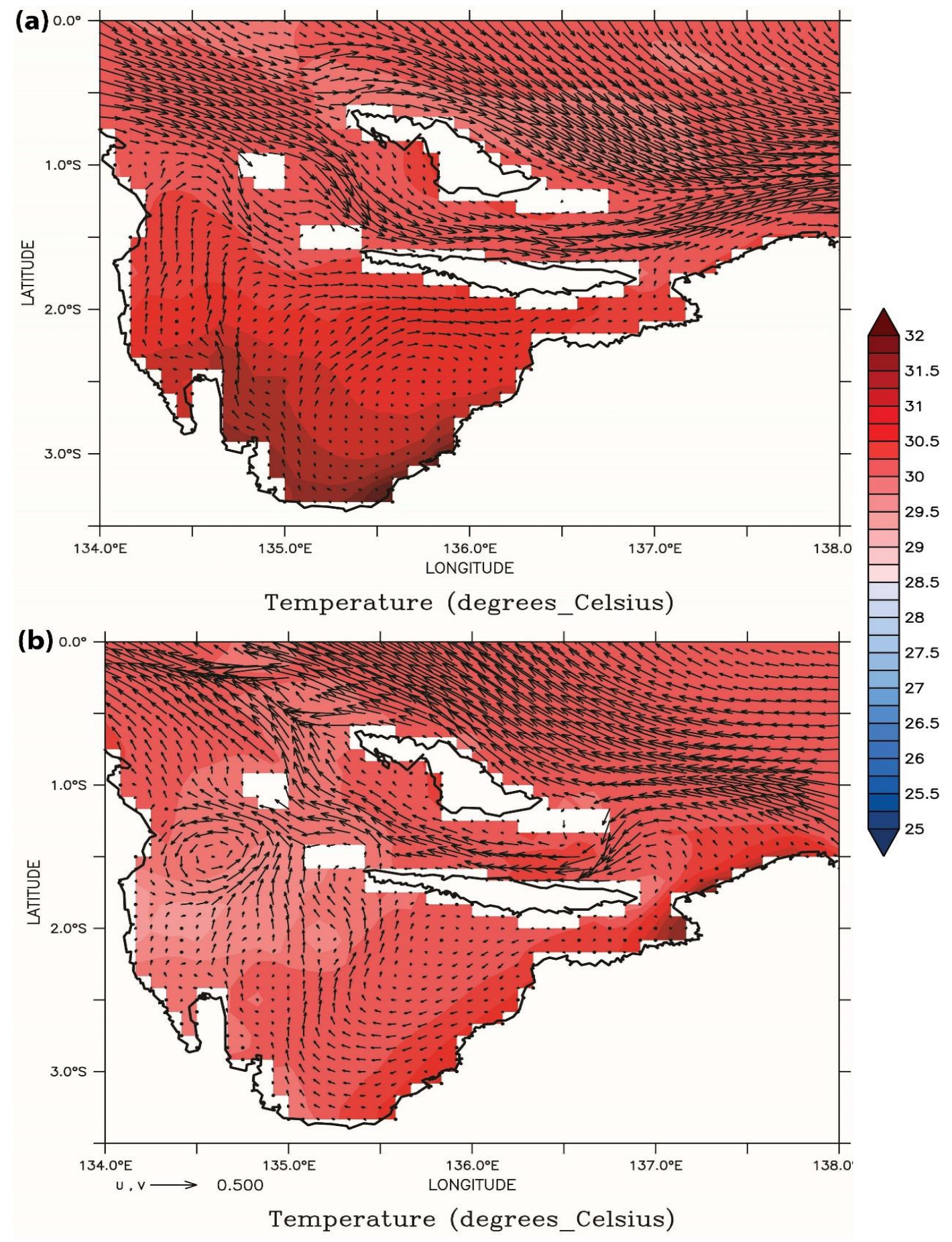

Figure 3. Current vectors distribution patterns overlayed with sea surface temperature in January 2015 (a) and in August 2015 (b) in Cendrawasih Bay. 


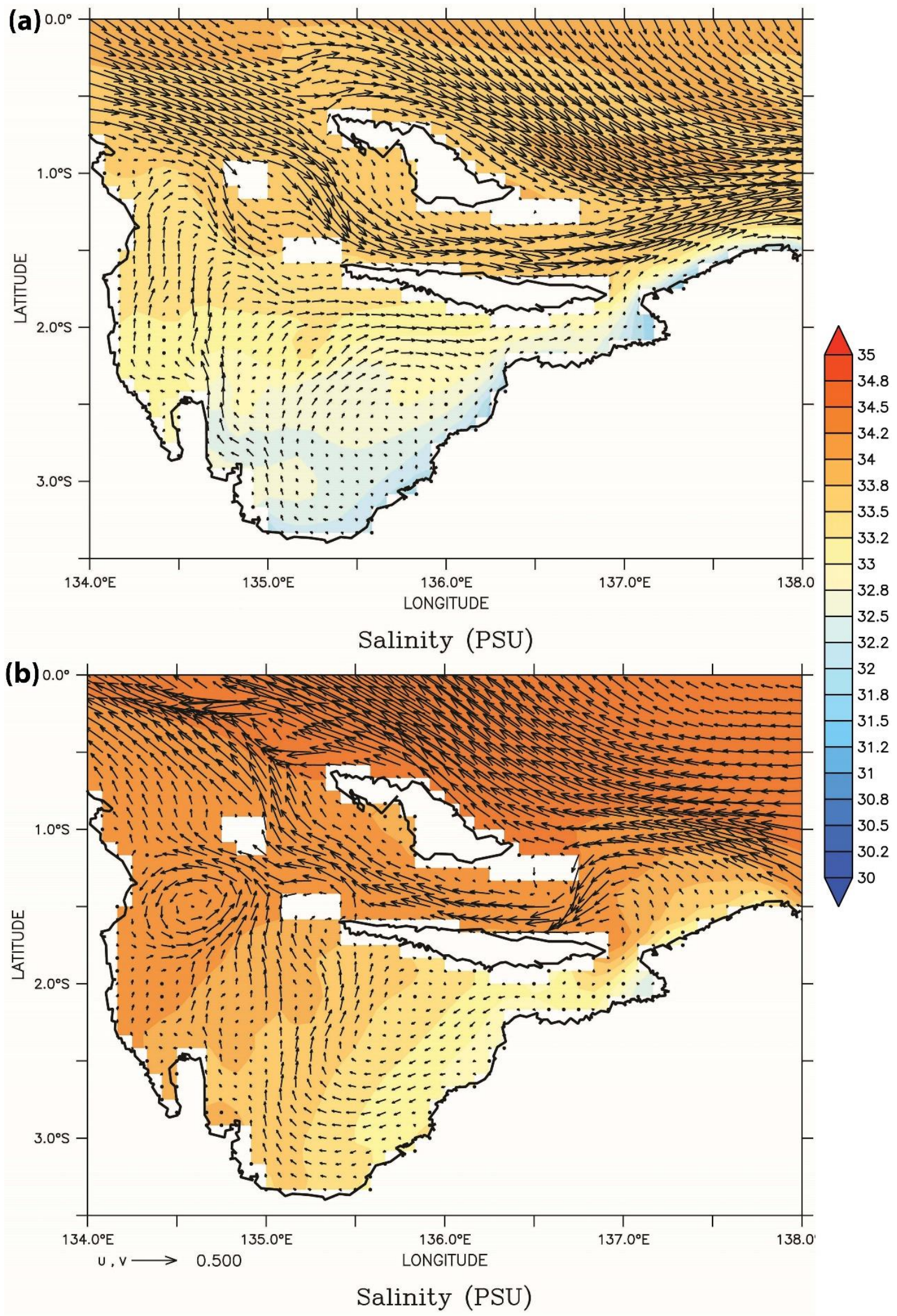

Figure 4. Current vectors distribution pattern overlayed with salinity in January 2015 (a) and August 2015 (b) in Cendrawasih Bay. 


\subsection{Discussion}

\subsubsection{Genetic Diversity}

Cendrawasih Bay is a region with high turtle biodiversity. L. olivacea type is known to spread evenly in the waters of Cendrawasih Bay from Yapen Island, Wondama to Nabire (Tapilatu, 2017). The results of the phylogenetic reconstructions illustrate the form of kinship between $L$. olivacea in the populations of Kwatisore and Yapen Island. It can be seen that even in the same waters both populations tend to form self-contained groups. However, individuals from Kwatisore which become the members of Yapen Island population group are found. This explains that there is connectivity between the populations of Kwatisore and Yapen Island so that phylogenetically there are individuals of L. olivacea join together in these two populations. The phylogenetic approach using the mitochondrial DNA can be used as a reference of kinship based on the geographic location, so it can indicate individual and species kinship through the reconstruction of phylogenetic trees in the study of genetic population (Nuryanto et al., 2007; Zuazo and Agnarson, 2010).

The haplotype diversity $(H d)$ in both populations showed a relatively low level of haplotype of L. olivacea in the range of 0 0.42857 . The low value of haplotype diversity in these waters indicates the small genetic variation of $L$. olivacea living in these waters. This is due to the Pattern in the waters of Cendrawasih Bay which has semienclosed characteristics that minimize the potential input of gene variations from outside these waters. Chiu et al. (2013) state that genetic diversity can be determined by two main factors, namely, habitat condition and excessive exploitation. Based on the observations conducted by Limpus, (1997) he stated that most marine turtle populations in the Indo Pacific Region experienced a

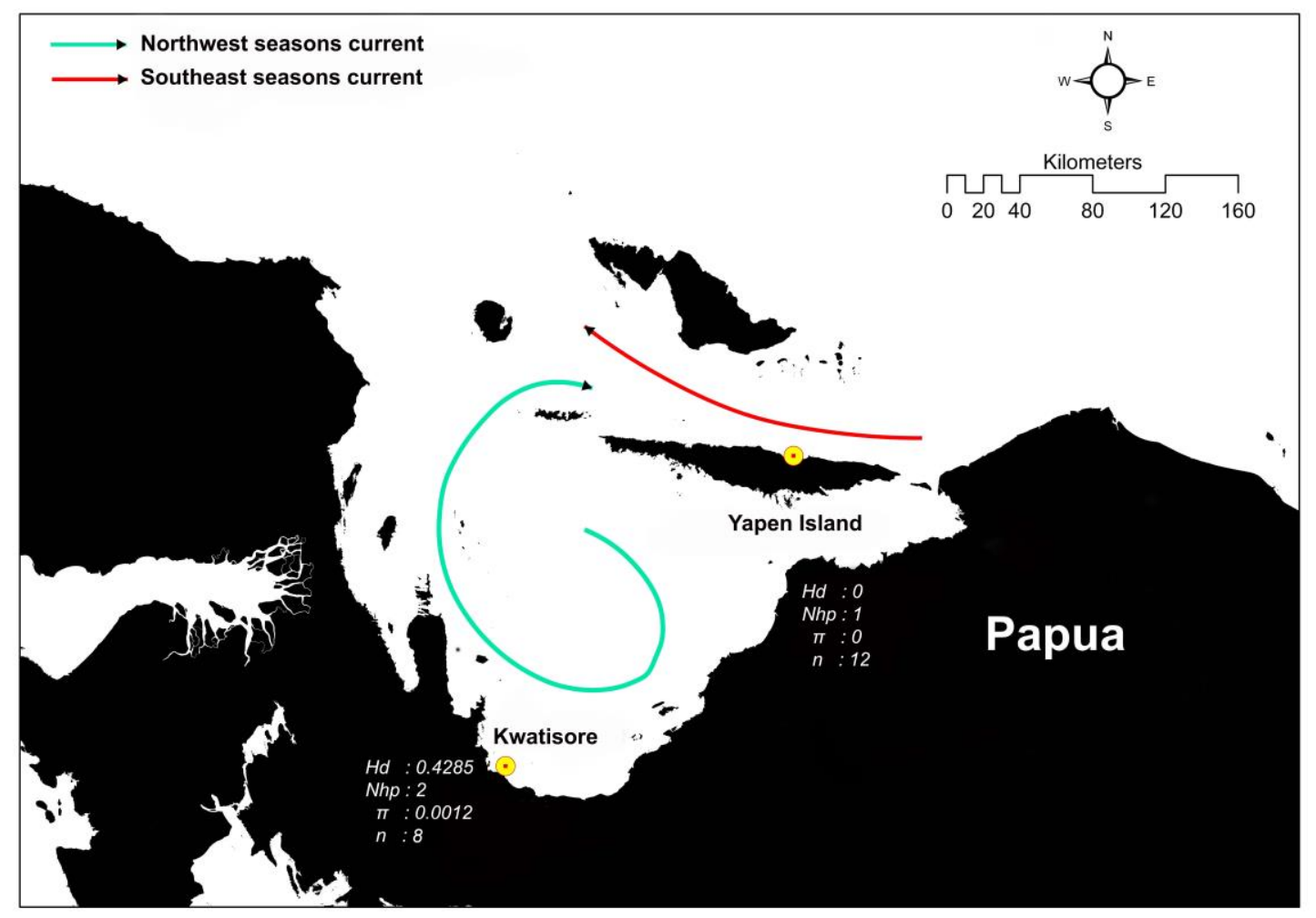

Figure 5. Schematic surface Pattern patterns during the Northwest (cyan arrow) and Southeast (red arrow) monsoons and genetic diversity of L. olivacea at Kwatisore and Yapen Island populations. 
significant decrease due to excessive exploitation, and this will indirectly reduce the genetic wealth of L. olivacea existing in these territorial waters. Despite its relatively low genetic diversity, L. olivacea Populations in Kwatisore and Yapen Islands are distinctly characterized, and this explains why Kwatisore waters have unique characteristics although Kwatisore and Yapen Islands are in the same area, In each population, in accordance with the statement of Himawan et al. (2015), the unique characteristics of marine species found in Cendrawasih Bay are not the same and not even found in other regions.

Based on the provisions set forth by Chargaff, the compositions of all nucleotides contained in living things follow the provision of a balanced number, in which the total of $\mathrm{A}+\mathrm{C}=\mathrm{G}+\mathrm{T}$ (Bel and Forsdyke, 1999). The nucleotide composition found in the study indicates an approximate value from the provision proposed by Chargaff. In general, the shift in values determined by Chargaff is only in the range of $0.02-1.46 \%$ so that this change does not have a significant impact on the translation of mtDNA. The shift of the value of nucleotide composition will affect the process of DNA translation where in the case of region coding stop codon will occur so that DNA cannot translate itself into protein. When a protein is not formed in accordance with the order performed by DNA, then there will be changes in protein translation, resulting in the error of the formation of the function of the protein itself. However, based on the value of the composition obtained from observations of $L$. olivacea, the number of comparison of nucleotides approaches the value set by the Chargaff rule so that it can still be categorized as normal.

\subsubsection{Current Pattern in the Eastern Archipelago}

The current pattern in the eastern archipelago, especially in the Cendrawasih Bay including Kwatisore and Yapen Islands is strongly influenced by the Southeast monsoons winds and the Indonesian Throughflow. The model output showed the current movement from the Halmahera to Papua New Guinea waters during the Northwest season, and it is vice versa during the Southeast season (Figure 3). The current movement in the northwest and south-eastern seasons in the Pacific Ocean passes through Cendrawasih Bay bordering directly with the Pacific Ocean. Cendrawasih Bay is strongly influenced by the Northwest and Southeast monsoons winds. The current movement in Cendrawasih Bay in the southeast season tends to move steadily following the movement of water masses from the waters of Papua New Guinea into the waters of Halmahera, but in the northwest season, the currents move from the waters of Halmahera and revolves around Cendrawasih Bay passing through the northern region of Yapen Island toward the waters of Papua New Guinea. This current movement was assumed to be the cause of the connectivity that has been linking of $L$. olivacea in Kwatisore Yapen Island populations.

The results of the current pattern analysis could be associated with the results of the phylogenetic analysis obtained from the molecular approach in which L. olivacea in Kwatisore population has been in one group with L. olivacea existing in Yapen Island population, indicating connectivity between these two populations. From the visualization of the current pattern obtained indicates that the current pattern vector tends to recirculate around the waters of Cendrawasih Bay in the Northwest season (in January) from Nabire region to Wondama Bay passing through the population of Kwatisore (Figure 5), and this phenomenon is thought to affect the spread of L. olivacea from hatchling Kwatisore region and its surrounding, as shown by high values of haplotype diversity, number of haplotypes and diversity of nucleotides in Kwatisore population compared to those of Yapen Island population although with fewer 
samples. Turtles can travel in migration with the distance up to $3,000 \mathrm{~km}$ by utilizing current as their movement media (Purnama et al., 2013; Luschi et al., 2003)

The results of the temperature analysis shows a uniform distribution of temperature in the western Pacific Ocean during the Northwest season where the average temperature reaches $28^{\circ} \mathrm{C}-32^{\circ} \mathrm{C}$ (Figure 4). It is known that at the beginning to mid-year the turtle nesting season in the northern waters of Papua is at its peak. Turtle tends to swim towards warmer waters in migrating and laying eggs (Luschi et al., 2003, Whiting et al., 2007) while in the southeast season, the surface temperature in the waters of the western Pacific Ocean tends to be warmer throughout the year. The distribution of salinity in the western Pacific Ocean has the tendency to be evenly distributed both in the northwest and southeast seasons. The average salinity ranges between $32 \mathrm{psu}$ and $35 \mathrm{psu}$. This condition is in accordance with the results of the research conducted by Atmadipoera et al. (2009) stating that the salinity around the waters of eastern Timor tends to be homogeneous up to the thermocline layer derived from the water mass flow of Banda Sea.

\section{CONCLUSION}

The population of $L$. olivacea in Kwatisore and Yapen Island is phylogenetically different which population from Australia is incorporated in one phylogeny with the Kwatisore population. This population has a higher gene variation than that of Yapen Island, and this is supported by the low value of haplotype diversity and nucleotide diversity in the population of Yapen Island.

Kwatisore and Yapen Island populations are connected through current pattern along the Papua coast to Papua New Guinea. This interaction occurs in the Northwest season where there is recirculation of current in the waters of the Kwatisore connecting the two populations. This pattern is thought to be a medium of interaction between the two populations that allows for genetic flow events in these two populations. The existing current based on the oceanographic observations confirms the genetic association of $L$. olivacea in Kwatisore and Yapen Island populations.

\section{ACKNOWLEDGMENTS}

This research was supported by Indonesia Endowment Fund for Education (LPDP). We appreciated to the Akmal Firdaus from Saireri Paradise Foundation, Yapen Island Regency, for their assistance during fieldwork for collecting samples, and to the editor and anonymous reviewers who have provided highly constructive suggestions and feedback for better writing of the paper.

\section{REFERENCES}

Alberto A.G., J. Horrocks, A. Formia, P. Dutton, R. LeRoux, X. VélezZuazo, L. Soares, and P. Meylan. 2006. New mtDNA Dloop primers which work for a variety of marine turtle species may increase the resolution of mixed stock analyses. In: Mike et al. (eds.). Proceedings of the $26^{\text {th }}$ annual symposium on sea turtle biology. Island of Crete, Greece: ISTS. 179179pp.

Atmadipoera, A.S., S.M. Horhoruw, M. Purba, dan D.Y. Yugroho. 2016. Variasi spasial dan temporal arlindo di Selat Makassar. J. Ilmu dan Teknologi Kelautan Tropis, 8(1):299320.

Atmadipoera, A., R. Molcard, G. Madec, S. Wijffels, J. Sprintall, A. KochLarrouy, I. Jaya, and A. Supangat. 2009. Characteristics and variability of the Indonesian throughflow water at the outflow straits. J. Deep-Sea Research I., 56:1942-1954. 
Baillie, J., C. Hilton-Taylor, and S.N. Stuart, 2004. 2004 IUCN red list of threatened species: a global species assessment. IUCN. Cambridge. 217p.

Bel, S.J. and Forsdyke D.R. 1999. Accounting Units in DNA. J. theor. Biol., 197: 51-61.

Bowen, B.W., A.M. Clark, F.A. AbreuGrobois, A. Chaves, H.A. Reichart, and R.J Ferl. 1998. Global phylogeography of the ridley sea turtles (Lepidochelys spp.) as inferred from mitochondrial DNA sequences. $J$. Genetica, 101:179-189.

Cahyani, N.K.D., W.I.B. Adnyana, dan I.W. Arthana. 2007. Identifikasi jejaring pengelolaan konservasi penyu hijau (Chelonia mydas) melalui penentuan komposisi genetik dan metal tag di Laut Sulu Sulawesi. J. Ecotrophic, 2(2):1-7.

Chaloupka, M., P. Dutton, and H. Nakano. 2004. Status of sea turtle stocks in the Pacific. J. Fisheries Report, 738:135164.

Chiu, Y., H. Bor, M. Tan, H. Lin, and C. Jean. 2013. Phylogeography and Genetic Differentiation among Populations of the Moon Turban Snail Lunella granulata Gmelin. 1791 (Gastropoda: Turbinidae). J. Int. Mol. Sci., 14:9062- 9079.

Collard, S.B. 1990. The influence of oceanographic features on post-hatchling sea turtle distribution and dispersion in the pelagic environment. In: Richardson et al. (eds.). Proc. 10th Ann. Symposium on Sea Turtle Biology and Conservation. NOAA Tech. Memo. NMFS-SEFC-278. South Carolina. 111-114pp.

Saleky, D., I. Setyobudiandi, H.A. Toha, M. Takdir, and H. Madduppa. 2016. Lengthweight relationship and population genetic of two marine gastropods species (Turbinidae: Turbo sparverius and Turbo bruneus) in the Bird Seascape Papua, Indonesia. J.
Biodiversitas, 17(1):208-217.

Dermawan, A., D. Soedharma, M.H. Halim, S. Nuitja, M.D. Kusrini, S.B. Lubis, R. Alhanif, dan M. Khazali. 2009. Pedoman teknis pengelolaan konservasi penyu. Direktorat Konservasi dan Taman Nasional Laut, Direktorat Jenderal Kelautan, Pesisir dan PulauPulau Kecil, Departemen Kelautan dan Perikanan RI. Jakarta. 63hlm.

Eckert, K.L., K.A. Bjorndal, F.A. AbreuGrobois, and M. Donnelly. 1999. Research and management techniques for the conservation of sea turtles. $J$. Chelonian Conservation and Biology, 3(3):538-538.

Gordon, A.L. and R.A. Fine. 1996. Pathways of water between the Pacific and Indian Oceans in the Indonesian Seas. J. Nature, 379:146-149.

Himawan, M.R., C. Tania, B.A. Noor, A. Wijonarno, B. Subhan, and H.H. Madduppa. 2015. Sex and size range composition of whale shark (Rhincodon typus) and their sighting behaviour in relation with fishermen lift-net within Cenderawasih Bay National Park, Indonesia. J. AACL Bioflux, 8(2):123-133.

Horhoruw, S.M. 2016. Struktur dan variabilitas arus lintas Indonesia di Selat Makassar. Thesis. IPB. 83hlm.

Horrocks, J.A., L.A. Vermeer, B. Krueger, M. Coyne, B.A. Schroeder, and G.H. Balazs. 2001. Migration routes and destination characteristics of postnesting hawksbill turtles satellitetracked from Barbados, West Indies. $J$. Chelonian Conservation and Biology, 4(1):107-114.

Ilahude, A.G. and A.L. Gordon. 1996. Thermocline stratification within the Indonesian Seas. J. of Geophysical Research, 101:12401-12409.

Kementerian Lingkungan Hidup. 2013. Deskripsi peta ekoregion laut Indonesia. IPB press. Jakarta. 230p.

Kochzius, M. and A. Nuryanto. 2008. Strong 
genetic population structure in the boring giant clam, Tridacna crocea, across the Indo-Malay Archipelago: implications related to evolutionary processes and connectivity. J. Molecular Ecology, 17:3775-3787.

Kusuma, A.B., D.G. Bengen, H.H. Madduppa, B. Subhan, dan D. Arafat. 2016. Keanekaragaman genetik karang lunak Sarcophyton trocheliophorum pada populasi Laut Jawa, Nusa Tenggara dan Sulawesi. $J$. Enggano, 1(1):89-96.

Limpus, C.J. 1997. Marine turtle populations of Southeast Asia and the western Pacific Region: distribution and status. Wetlands International, PHPA/ Environment. Australia. 73p.

Luschi, P., G.C. Hays, and F. Papi. 2003. A review of long-distance movements by marine turtles, and the possible role of ocean currents. J. Oikos, 103:293-302.

Madduppa, H.H., R.U. Ayuningtyas, B. Subhan, D. Arafat, and Prehadi. 2016. Exploited but unevaluated: DNA Barcoding reveals skates and stingrays (Chordata, Chondrichthyes) species landed in the Indonesian fish market. J. Ilmu Kelautan, 21(1):29-36.

Madec, G. 2015. NEMO ocean engine. Institut Pierre-Simon Laplace (IPSL). France. 401p.

Maslim, A. Farajallah, and N.P. Zamani. 2016. Leatherback turtle (Dermochelys coriacea) populations in Sumatra: genetic diversity and connectivity pattern. J. Bioflux, 9(2):276283.

Meylan, A.B. and M. Donnelly. 1999. Status justification for listing the hawksbill turtle (Eretmochelys imbricata) as critically endangered on the 1996 IUCN red list of threatened animals. J. Chelonian Conservation and Biology, 3(2):200-224.

Murray, S.P. and D. Arief. 1988. Throughflow into the Indian Ocean through the Lombok Strait january 1985 january 1986. J. Nature, 333:444-447.

Musick, J.A. and C.J. Limpus. 1997. Habitat utilization and migration in juvenile sea turtles. J. The biology of sea turtles, 1:137-163.

Mustikasari, E., L.C Dewi, A. Heriati, dan W.S. Pranowo. 2015. Pemodelan pola arus barotropik musiman 3 dimensi (3D) untuk mensimulasikan fenomena upwelling di perairan Indonesia. J. Segara, 11(1):25-35.

Nuryanto, A., D. Duryadi, D. Soedharma, and D. Blohm. 2007. Molecular phylogeny of giant clams based on mitochondrial dna cytochrome $\mathrm{C}$ oxidase I gene. J. Hayati of Biosciences, 14(4):162-166.

Purnama, D., N.P. Zamany, and A. Farajallah. 2013. Microsatellite dna analysis on the polyandry of green sea turtle Chelonia mydas. J. Hayati of Biosciences, 20(4):182-186.

Polovina, J.J., G.H. Balazs, E.A. Howell, D.M. Parker, M.P. Seki and P.H. Dutton. 2004. Forage and migration habitat of loggerhead (Caretta caretta) and olive ridley (Lepidochelys olivacea) sea turtles in the central North Pacific Ocean. J. Fish Ocean. 13:36-51.

Prehadi, A. Sembiring, E.M. Kurniasih, Rahmad, D. Arafat, B. Subhan, and H Madduppa. 2015. DNA barcoding and phylogenetic reconstruction of shark species landed in Muncar fisheries landing site in comparison with Southern Java fishing port. $J$. Biodiversitas, 6(1):55-61.

Rodríguez-Zárate, C.J., A. Rocha-Olivares, and L.B. Beheregaray. 2013. Genetic signature of a recent metapopulation bottleneck in the olive ridley turtle (Lepidochelys olivacea) after intensive commercial exploitation in Mexico. J. Biol. Conserv., 168:10-18.

Rozas, J., J.C. Sanches-Del, X. Messeguer, and R. Rozas. 2003. DnaSP, DNA 
Polymorphism analyses by the coalescent and other methods. $J$. Bioinformatics Aplications Note, 19:2496-2497.

Tamura, K., G. Stecher, D. Peterson, A. Filipski, and S. Kumar. 2011. MEGA6: molecular evolutionary genetics analysis version 6.0. J. Molecular Biology and Evolution, 30(12): 2725-2729.

Tapilatu, R.F., H. Wona, and P.P. Batubara. 2017. Status of sea turtle populations and its conservation at Bird's Head Seascape, Western Papua, Indonesia. J. Biodiversitas, 18:129-136.

Tranchant, B., G. Rerray, E. Greigner, D. Nugroho, A. Koch-Larrouy, and P. Gaspar. 2015. Evaluation of an operational ocean model configuration at $1=12^{\circ} \mathrm{C}$ spatial resolution for the Indonesian seas - Part 1: Ocean physics. J. Geosci. Model Dev.
Discuss., 8:6611-6668.

Walsh, P.S., D.A. Metzger, and R. Higuchi. 1991. Chelex-100 as a medium for simple extraction of DNA for PCR based typing from forensic material. J. Biotechniques, 10:506-513.

Whiting, S., J. Long, and M. Coyne. 2007. Migration routes and foraging behaviour of olive ridley turtles (Lepidochelys olivacea) in northern Australia. J. Endanger Species sRes., $3: 1-9$.

Zuazo, X.V. and I. Agnarson. 2010. Shark tales: A molecular species-level phylogeny of sharks (Selachimorpha, Chondrichthyes). J. Molecular Phylogenetics and Evolution, 58:207-217.
Diterima : 24 Juli 2017
Direview : 02 Agustus 2017
Disetujui : :04 Desember 2017 